\title{
PENGEMBANGAN KONSTRUK INSTRUMEN HASIL PEMBELAJARAN PRAKTIK KARAWITAN JAWA
}

\author{
Budi Raharja, Suminto A. Sayuti \\ Insitut Seni Indonesia Yogyakarta, Universitas Negeri Yogyakarta \\ budi_raharja@hotmail.com,suminto1956@yahoo.com
}

\begin{abstract}
Abstrak
Penelitian ini mengembangkan instrumen hasil pembelajaran praktik karawitan Jawa dari perspektif keterampilan dan sikap. Perspektif keterampilan menilai kemampuan peserta didik menyelaraskan komponen pembelajaran (melodi, irama/tempo, dan bunyi/nada); sedangkan perspektif sikap menilai pemahaman, penghayatan, dan pengamalan komponen pembelajaran tersebut. Langkah-langkahnya meliputi pengembangan produk, validasi produk, implementasi produk, dan analisis data. Pengembangan produk meliputi pengembangan instrumen keterampilan dan pengembangan instrumen sikap; validasi produk menguji produk dalam diskusi kelompok terfokus, seminar instrumen, dan validasi ahli; implementasi produk adalah mengaplikasikan instrumen dalam uji coba skala kecil dan skala besar serta uji coba utama; sedangkan analisis datanya menggunakan uji kecocokan model. Hasil uji kecocokan model menyatakan bahwa model dinyatakan fit dengan koefisien korelasi antara 0,90 hingga 0,98 dan muatan faktor antara 0,62 hingga 0,91. Instrumen menghasilkan informasi kemampuan menyelaraskan melodi, irama, dan bunyi ricikan serta karakteristik tabuhan peserta didik dari perspektif dan pemahaman, penghayatan, dan pengamalan komponen pembelajarannya.
\end{abstract}

Kata kunci: karawitan, penilaian, keterampilan, sikap

\section{DEVELOPING AN INSTRUMENT CONSTRUCT FOR ASSESSING THE JAVANESE KARAWITANLEARNING OUTCOME}

\author{
Budi Raharja, Suminto A. Sayuti \\ Insitut Seni Indonesia Yogyakarta, Universitas Negeri Yogyakarta \\ budi_raharja@hotmail.com, suminto1956@yahoo.com
}

\begin{abstract}
This study developed an instrument for assessing learning achievement of Javanese karawitan practice from the perspectives of skill and attitude. The skill perspective evaluates the students' ability to harmonize the learning components (melody, rhythm/tempo, and sound/tone); while the attitude perspective evaluates their understanding, comprehension, and application of those learning components. The steps in doing the research include product development, product validation, product implementation, and data analysis. Product development includes developing the skill instruments and developing the attitude instruments; while product validation includes testing the product in focus group discussion, seminar for the instruments, and expert judgment. Product implementation is applying the instrument in small-scale and large-scale tests as well as main testing, while the data analysis used model fitness test. The result of model fitness test shows that this model is fit with correlation coefficient from 0.90 to 0.98 and content factor from 0.62 to 0.91 . The instrument has yielded information concerning the ability of students to harmonize melody, rhythm, and the ricikan and tabuban sounds from the perspectives of understanding, comprehending, and applying the learning components.
\end{abstract}

Keywords: karawitan, assessment, skill, and attitude 


\section{Pendahuluan}

Instrumen hasil pembelajaran praktik karawitan Jawa di perguruan tinggi seni Indonesia pada saat ini belum ideal. Alat ukur tersebut memberi keleluasaan kepada penguji untuk menafsirkan hasil pembelajaran tersebut sesuai persepsi masingmasing. Hasil interviu dengan tiga pengajar di ISI Surakarta dan ISI Yogyakarta menunjukkan bahwa mereka mengukur hasil pembelajaran dengan menggunakan perspektif, dimensi, dan sistem penskoran masing-masing.

Djoko Maduwiyoto, pengajar jurusan Karawitan ISI Yogyakarta (wawancara tanggal 22 Januari 2011), menggunakan dimensi hafalan (gending), bener (kesesuaian melodi dan ritme), tingkat keterampilan, dan kualitas tabuhan; Bambang Sri Atmojo, teman Djoko Maduwiyoto (wawancara tanggal $12 \mathrm{Ja}$ nuari 2011), menggunakan dimensi hafalan (gending), teknik (cara memainkan alat musik), dan rasa; sedangkan Darno (pengajar Jurusan Karawitan ISI Surakarta) (wawancara tanggal 24 Mei 2012) menggunakan hafalan, kualitas melodi, kualitas bunyi, dan tempo.

Meskipun mereka mengggunakan dimensi pengukuran jamak, hasil penilaiannya tidak mencerminkan dimensi-dimensi yang dimaksud. Hasil penilaiannya berupa skor tunggal ricikan. Skor-skor tersebut, karena belum ada pedoman penskoran, masingmasing penguji menggunakan sistem penskoran berbeda, misalnya menggunakan huruf ( $\mathrm{A}, \mathrm{B}, \mathrm{C}$, dan seterusnya), gabungan huruf dengan tanda plus dan minus $\left(\mathrm{B}+, \mathrm{A}_{-}\right.$, dan seterusnya), angka dalam ukuran pecahan $(3,81,3,50,3,75$, dan seterusnya) atau angka tanpa pecahan $(2,3,4,1)$, dan lainlain. Aplikasi sistem penskoran tersebut, misalnya skor rebab 3,85, skor kendang 3, skor gender barung $\mathrm{C}+$, dan sejenisnya. Skor-skor tersebut dijumlah dan dikonversi menjadi nilai hasil pembelajaran praktik karawitan.

Hasil penilaian tersebut belum dapat digunakan secara optimal bagi pengembangan pendidikan; karena belum menghasilkan informasi tentang kompetensi dasar yang telah dan belum dicapai peserta didik (Mardapi, 2004, pp.75-76). Informasi ini penting bagi peserta didik karena dapat dijadikan bahan menentukan strategi belajarnya, sedangkan bagi pendidik sebagai bahan untuk menentukan strategi mengajarnya. Strategi yang dimaksud misalnya menentukan fokus belajarnya peserta didik atau bagi pendidik digunakan untuk menentukan fokus pengajarannya. Hasil penilaian demikian belum dapat difungsikan sebagai (a) umpan balik yang efektif bagi peserta didik; (b) mendorong peserta didik belajar mandiri; (c) umpan balik guru untuk memperbaiki pembelajarannya; (d) bahan pengajar memahami pengaruh evaluasi (penilaian) terhadap motivasi siswa dan kepercayaan dirinya; (e) peserta didik melakukan monitoring dan koreksi diri serta mendorong terciptanya life long learning (Zamroni, 2004, p.42).

Hasil penilaian tersebut seharusnya berisi informasi tentang perolehan pengetahuan, keterampilan, dan perilaku (Suminto, 2004, p.17) atau mutu proses pembelajaran, seberapa tepat proses belajar itu dilaksanakan (Sodikun, 2004, p. 87). Johnson dan Johnson (2002, p.3) menambahkan sistem penilaian yang ideal menghasilkan informasi (a) tentang tujuan penilaian yang berguna bagi pemangku kepentingan; (b) terdiri atas prosedur yang mudah dimengerti; (c) menyediakan petunjuk yang jelas bagi peningkatan kualitas pembelajaran dan pengajaran.

Informasi hasil pembelajaran yang baik juga dapat digunakan untuk membentuk opini publik, membantu pelaksanaan evaluasi (kualitas) guru, dan alat klarifikasi perhatian guru mengajar. Pembentuk opini publik maksudnya informasi keberhasilan sekolah dalam melaksanakan pembelajaran yang ditandai dengan prestasi anak didik mampu membentuk nama baik sekolah. Kedua pelaksanaan penilaian dapat digunakan untuk mengevaluasi kinerja guru, misalnya ketika guru diperintah membuat pretest dan postest dapat diketahui seberapa besar sistem pembelajarannya didukung. Mengukur perhatian guru dapat dilihat dari hasil penilaian, maksudnya ketika guru menginginkan hasil pembelajarannya bagus mereka akan memfokuskan pada pengembangan pembelajarannya (Popham, 1995, pp.8-12). 
Uraian di atas memberi gambaran bahwa informasi penilaian hasil pembelajaran mempunyai peran penting bagi pengembangan pendidikan. Hasil penilaian merupakan salah satu bahan penting untuk menentukan arah pembelajaran, bahan evaluasi pembelajaran, dan lain sebagainya. Mengingat sangat penting posisinya tersebut, pengembangan instrumen hasil pembelajaran tersebut merupakan kebutuhan mendesak. Terkait dengan hal tersebut, pengembangan konstruk instrumen penilaian hasil pembelajaran Karawitan Jawa merupakan hal yang urgen.

Tujuan penelitian ini merancang instrumen hasil pembelajaran rebab, kendang, dan gender barung. Dua permasalahan dibahas dalam diskusi ini, yaitu bagaimanakah konstruk penilaian hasil pembelajaran rebab, kendang, dan gender barung dan bagaimanakah instrumen hasil pembelajaran rebab, kendang, dan gender tersebut.

\section{Metode Penelitian}

Metode penelitian yang digunakan dalam penelitian pengembangan konstruk instrumen hasil pembelajaran praktik karawitan Jawa ini dapat dijelaskan sebagai berikut.

Penelitian pengembangan konstruk instrumen hasil pembelajaran praktik karawitan Jawa merupakan jenis penelitian pengembangan. Menurut Borg \& Gall (1983, p.772) penelitian pengembangan adalah serangkaian kegiatan penelitian yang terdiri atas kegiatan mengembangkan dan memvalidasi produk pendidikan melalui reviu temuan penelitian terkait, mengembangkan produk berdasarkan temuan, mengujicobakan hasil rancangan, merivisi untuk perbaikan hingga ditemukan model ideal.

Penelitian pengembangan ini dilaksanakan mulai tanggal 18 April 2011 sampai dengan tanggal 15 Desember 2013. Penelitian diadakan di Jurusan Karawitan, $\mathrm{Fa}$ kultas Seni Pertunjukan, Institut Seni Indonesia Surakarta.

Subjek penelitian ini dikelompokkan ke dalam subjek penelitian tahap pengembangan dan subjek penelitian tahap imple- mentasi produk. Subjek penelitian tahap pengembangan adalah mereka yang terlibat dalam Focus Group Discussion, Seminar Instrumen, dan Validasi Ahli; sedangkan subjek penelitian tahap implementasi produk adalah mereka yang terlibat dalam uji coba lapangan.

Subjek penelitian dalam Focus Group Discussion (FGD) terbagi dalam subjek penelitian FGD 1 dan subjek penelitian FGD 2. Subjek penelitian FGD1 adalah pengajar dan pengelola jurusan Karawitan ISI Surakarta, tokoh karawitan gaya Surakarta, dan ahli karawitan Jawa; sedangkan subjek penelitian FGD 2 adalah pengajar dan pengelola jurusan Karawitan, pengajar jurusan Tari, pengajar Etnomusikologi ISI Yogyakarta, tokoh karawitan gaya Yogyakarta dan Surakarta, Ahli Pendidikan Seni, Ahli Karawitan Jawa, dan Widya Iswara dari P4TK Yogyakarta.

Subjek penelitian Seminar Instrumen adalah dua ahli evaluasi pendidikan dan sepuluh mahasiswa S3 Program Pascasarjana Universitas Negeri Yogyakarta; subjek validasi ahli adalah ahli pendidikan seni, ahli evaluasi pendidikan, dan ahli karawitan Jawa; sedangkan subjek implementasi produk dibedakan dalam subjek uji coba lapangan skala kecil, subjek uji coba skala besar, dan subjek uji coba utama. Subjek penelitian uji coba skala kecil adalah 30 orang mahasiswa semester dua dan tiga orang dosen jurusan Karawitan ISI Surakarta; subjek uji coba skala besar adalah dua puluh tiga orang mahasiswa semester dua dan tujuh orang mahasiswa semester empat, dan tiga orang pengajar; sedangkan subjek uji coba utama adalah mahasiswa semester dua lima puluh tujuh orang mahasiswa, mahasiswa semester empat 29 orang mahasiswa, dan mahasiswa semester enam tiga belas mahasiswa jurusan Karawitan ISI Surakarta dan tiga dosen.

Gending yang diujicobakan dalam uji coba skala kecil adalah gending Ketawang Subakatawa Laras Slendro Pathet Sanga, sedangkan pada uji coba skala besar dan uji coba utama adalah gending Ketawang Subakatawa Laras Slendro Pathet Sanga, dan gending Ladrang Wilujeng Laras Slendro Patet Manyura. 
Prosedur penelitian pengembangan ini meliputi pembentukan tim perancang produk awal, penumpulan data awal, penyusunan produk awal (instrumen keterampilan dan instrumen sikap), dan uji coba produk. Tim perancang produk awal dibentuk dengan susunan kepengurusan ketua Suraji (ketua Jurusan Karawitan ISI Surakarta), sedangkan anggotanya adalah Darno (Sekretaris Jurusan Karawitan ISI Surakarta), Hadi Budiono (Kepala Studio Jurusan Karawitan ISI Surakarta), Rusdiantoro (Pengajar Jurusan Karawitan ISI Surakarta), dan Budi Raharja (peneliti).

Tim bertugas merancang produk awal dan merevisinya berdasarkan masukan yang didapat selama proses penelitian. Sesuai dengan pokok permasalahan yang diangkat dalam penelitian ini, produk yang dirancang berupa instrumen keterampilan dan instrumen sikap memainkan rebab, kendang, dan gender barung. Pengembangan meliputi perancangan konstruk instrumen dan perancangan instrumen hasil pembelajaran.

Pengumpulan data awal merupakan pengumpulan data yang berhubungan dengan data untuk penyusunan draf awal instrumen keterampilan memainkan rebab, kendang, dan gender barung. Data yang dimaksud adalah data hasil pembelajaran praktik karawitan Jawa hasil pengamatan kelas dan data teori gerak. Keduanya digunakan sebagai bahan penyusunan draf awal instrumen keterampilan hasil pembelajaran praktik karawitan Jawa. Hasil pengembangan instrumen keterampilan tersebut dijadikan dasar penyusunan instrumen sikap memainkan rebab, kendang, dan gender barung.

Hasil rancangan diujicobakan dalam uji konseptual dan uji coba lapangan. Uji coba konseptual dilakukan dalam Diskusi Kelompok Kerfokus (Focus Group Discussion), seminar instrumen, dan uji lapangan. diskusi kelompok terfokus diselenggarakan dua kali (diskusi kelompok kerfokus 1 dan diskusi kelompok terfokus 2), seminar instrumen dan validasi oleh ahli masingmasing dilakukan satu kali, sedangkan uji lapangan dilakukan dalam tiga tahap, uji coba skala kecil, uji coba skala besar, dan implementasi.

Pengembangan Konstruk Instrumen Hasil Pembelajaran Praktik Karawitan

Pengembangan konstruk instrumen hasil pembelajaran praktik karawitan merupakan kegiatan menemukan dimensi pengukuran dan indikator (Azwar, 2005, p.16) hasil pembelajaran tersebut. Dimensi pengukuran hasil pembelajaran praktik karawitan Jawa berupa dimensi keterampilan dan dimensi sikap memainkan gamelan Jawa.

Pengembangan Konstruk Instrumen Keterampilan

Pengembangan konstruk instrumen hasil pembelajaran keterampilan pada dasarnya adalah pengukuran komponen-komponen dalam bekerja sama menggarap gending Jawa. Komponen tersebut, karena merupakan pembelajaran musik, dapat diidentifikasi dengan menggunakan pendekatan komponen musik dan komponen khusus pembelajaran tersebut.

Menurut Scruton (1999, p.309) komponen musik terdiri atas melodi, ritme, dan harmoni; sedangkan komponen khusus pembelajaran praktik karawitan adalah teknik karawitan. Berdasarkan diskusi tersebut komponen hasil pembelajaran praktik karawitan adalah melodi, harmoni, ritme, dan teknik karawitan.

Melodi adalah satu kesatuan pergerakan nada yang menjadi jiwanya musik. Wujud melodi adalah pergerakan naik dan turun, cepat dan lambat nada dalam ruang dan waktu (Machlis, 1955, p.14). Melodi merupakan ide utama musik atau objek utama yang didengar dan menjadi faktor penting dalam ritme dan harmoni. Susunan nada tersebut membentuk fungsi nada (nada kuat, nada lemah, dan sejenisnya) dan interval atau jarak antarnada.

Melodi-melodi tersebut diwadahi dalam satuan ketukan. Satuan ketukan melodi musik Barat disebut birama; yaitu susunan ajeg (sejumlah ketukan) yang terikat oleh 
sistem tekanan tetap (Prier, SJ., 1991, p.90) yang membentuk pola ketukan berat dan ringan yang dalam musik Barat ketukan terberat terletak di ketukan pertama.

Melodi karawitan Jawa (gending Jawa) terdiri atas melodi pokok dan melodi ricikan. Melodi pokok, disebut juga balungan gending, adalah susunan nada yang membentuk kerangka gending; sedangkan melodi ricikan adalah cengkok atau pola melodi yang dimainkan oleh rebab dan gender barung atau pola tabuhan yang dimainkan oleh bonang barung, bonang penerus, dan saron penerus untuk menghias melodi pokok.

Melodi pokok karawitan dirangkai dalam kesatuan empat ketukan dan disebut gatra. Setiap gatra balungan gending terdiri atas empat jenis ketukan, yaitu ketukan sangat lemah (ketukan pertama dan ketiga), ketukan kuat (ketukan kedua), dan ketukan sangat kuat (ketukan keempat) (Martopangrawit, 1975, pp.57-58). Ketukan sangat kuat dijadikan rujukan pemain ricikan gamelan untuk membuat lagu atau melodi ricikan (Supanggah, 2004, p.2). Contoh pemain gender barung dalam memilih cengkok selalu didasarkan atas nada-nada seleb tersebut.

Dalam pembelajaran praktik karawitan, melodi ricikan merupakan materi ajar pokok. Materi tersebut diberikan secara bertahap, pembelajaran tahap pengenalan cengkok berupa pengenalan cengkok-cengkok yang digunakan untuk menggarap gending alit; pada tahap pengayaan cengkok peserta didik diberi materi pengayaan cengkok yang digunakan untuk menggarap gending tengahan; sedangkan pada pembelajaran tahap aplikasi cengkok peserta didik diberi latihan mengaplikasikan cengkok yang sudah dikuasai untuk menggarap gending yang sudah maupun belum pernah diberikan dalam perkuliahan.

Teknik karawitan adalah matakuliah tentang cara membunyikan gamelan. Teknik rebab merupakan mata kuliah yang berisi pengetahuan dan keterampilan memainkan rebab. Materi ajar teknik rebab meliputi (1) steman; (2) teknik kosokan; (3) tata jari; dan (4) posisi jari. Steman rebab adalah cara menentukan nada kawat rebab; kawat per- tama (kiri) diselaraskan dengan nada nem (6) dan nada kawat kedua (kanan) diselaraskan dengan nada loro (2). Masalah penting dalam steman rebab adalah keselarasan dan kejernihan bunyi rebab; keselarasan bunyi rebab adalah kesesuaian antara nada rebab dengan nada gamelan atau ricikan lain; sedangkan kejernihan bunyi rebab adalah menyatunya (kempel) bunyi dua kawat rebab tersebut.

Teknik kosokan adalah cara menggesek kawat rebab. Hal penting dan perlu diperhatikan dalam menggesek kawat rebab adalah penggesekan tidak dilakukan di posisi mati; tempat getar kawat yang pada rebab yang terletak di bagian atas, dekat srenten atau penyangga kawat rebab. Penggesekan pada tempat tersebut menghasilkan bunyi rebab ngerik, bunyi tidak nyaring ("ngik" "ngik").

Tata jari adalah penataan fungsi jari, yaitu pemanfaatan empat jari (telunjuk, jari tengah, kelingking, dan jari manis) untuk menghasilkan bunyi atau laras rebab. Fungsi jari dalam bermain rebab merupakan pedoman yang dibuat untuk memudahkan memainkan rebab; jari telunjuk berada pada nada paling rendah dari setiap pola melodi yang dimainkan.

Posisi jari adalah peran masingmasing jari dalam menghasilkan bunyi atau nada rebab yang dikaitkan dengan wilayah nada. Terdapat lima posisi jari dalam laras Slendro, yaitu posisi satu, dua, tiga, empat, dan posisi lima. Posisi-posisi tersebut terbentuk dari perubahan letak jari telunjuk hingga jari kelingking dalam menghasilkan nada rebab. Posisi-posisi jari yang dimaksud adalah posisi pertama letak jari telunjuk pada nada 1, jari tengah pada nada 2, jari manis pada nada 3, dan jari kelingking pada nada 5; posisi jari 2 letak jari telunjuk pada nada 2, posisi jari ketiga jari telunjuk pindah ke nada 3, dan seterusnya hingga pada posisi kelima posisi jari telunjuk pada nada 6 (atas) (Djumadi, 1982, p.21). Peserta didik harus menguasai teknik-ktenik tersebut agar dalam memainkan rebab dihasilkan nada yang selaras dengan nada ricikan lain. 
Pembelajaran teknik kendang merupakan latihan menghasilkan bunyi kendang. Permasalahan penting dalam pembelajaran kendang adalah steman, kebukan, dan keseimbangan bunyi antara bunyi hasil kebukan tangan kiri dengan bunyi hasil kebukan tangan kanan. Steman adalah penyelarasan bunyi kendang dengan nada atau laras gamelan; bunyi kendang dikatakan selaras apabila bunyi "thung" selaras dengan bunyi nada yang terletak antara nada 3 dengan nada 5, sedangkan bunyi "dhah" selaras dengan nada 2.

Kebukan adalah cara memukul tebokan (membran) kendang untuk menghasilkan bunyi kendang. Bunyi kendang (kendang ketipung, kendang cilbon, dan kendang ageng) berasal dari tebokan alit (membran berukuran kecil) dan tebokan ageng (membran berukuran besar). Masing-masing tebokan (bagian tengah dan pinggir) tersebut menghasilkan bunyi berbeda-beda. Bunyi-bunyi tersebut dirangkai menjadi berbagai macam pola ritme atau kendangan, kendangan gending lancaran, gending ketawang, gending ladrang, dan gending-gending lainnya. Peserta didik harus dapat memainkan pola ritme tersebut untuk mengedalikan irama/ tempo gending.

Pembelajaran teknik gender barung merupakan latihan cara menghasilkan bunyi gender barung. Pembelajaran diawali dengan pengenalan bagian-bagian ricikan gender barung, tabuh gender barung serta fungsi bagian-bagiannya dalam menghasilkan bunyi gender barung. Pengenalan bagian-bagiannya difokuskan pada bagian yang ada kaitannya dengan teknik penyuaraan; antara lain tempat menabuh, cara menabuh, dan cara menghen-tikan atau mematet bilah gender.

Setelah pengenalan bagian-bagiannya, pembelajaran dilanjutkan dengan cara menabuh dan mematet bilah. Pembelajaran cara menabuh dimulai dengan pembelajaran cara memegang tabuh, yaitu gagang tabuh diapit jari telunjuk dan jari tengah; sedangkan telapak tangan menekan bagian pangkal tabuh. Cara menabuh bilah adalah tabuh dipukulkan pada bagian tengah bilah dengan posisi tangan kanan dan posisi telapak tangan tengkurep, sedangkan posisi tangan kiri miring. Teknik pematetan untuk tangan kanan menggunakan ibu jari dan jari kelingking, namun untuk tangan kiri menggunakan ibu jari dan pangkal ibu jari, jari telunjuk, dan pangkal jari kelingking. Pemathetan dilakukan setelah menabuh bilah yang lain.

Pembelajaran cara memainkan cengkok gender barung diawali dengan pembelajaran tangan kanan dan tangan kiri memainkan potongan cengkok dengan teknik gembyang atau tabuhan bersama dua nada berjarak satu oktaf. Setelah teknik gembyang dikuasai dilanjutkan dengan teknik tabuhan tangan kanan dan tangan kiri menabuh dengan gerakan secara berlawanan, baik untuk cengkok yang berakhir dengan tabuhan kempyung maupun tabuhan gembyang. Setelah teknikteknik tersebut dikuasai dilanjutkan dengan pembelajaran cara memainkan cengkok.

Berdasarkan diskusi tersebut komponen pembelajaran praktik karawitan Jawa adalah melodi atau cengkok, ritme atau ira$\mathrm{ma} /$ tempo, keseimbangan bunyi, dan keselarasan bunyi. Cengkok dalam pembahasan kualitas tabuhan mengukur tingkat kerumitannya (kerawitannya), irama/tempo mengukur kerampakan tabuhuan, keseimbangan bunyi mengukur kerempegan tabuhan, sedangkan keselarasan bunyi mengukur kesesuaian atau keselarasan bunyi masing-masing ricikan.

Komponen hasil pembelajaran praktik karawitan Jawa adalah rawit, laras, rampak, rempeg. Rawit mengukur tingkat kerumitan melodi, laras mengukur tingkat keselarasan bunyi, rampak mengukur kerampakan/kebersamaan tabuhan, sedangkan rempeg mengukur keseimbangan bunyi tabuhan.

Pengukuran atas komponen-komponen tersebut menggunakan pedoman penilaian yang disusun berdasarkan teori gerak dan tingkatan hasil pembelajaran praktik karawitan 1 hasil pengamatan kelas.

Menurut teori terdapat empat tingkatan gerak, yaitu (a) gerak kognitif; (b) gerak asosiatif; dan (c) gerak otomatis. Gerak kognitif adalah capaian gerak yang masih mengandung banyak kesalahan dan kesalah- 
an cenderung berat; gerak asosiatif adalah capaian gerak dengan ciri gerak yang dilakukan sudah lebih baik dibanding gerak kognitif, tetapi masih mengandung kesalahan dan kesalahan cenderung ringan; sedangkan gerak otomatis adalah gerak yang sudah tidak lagi ada kesalahan dan gerak yang dilakukan sudah secara otomatis dan dioptimalkan (Magill, 1993, pp.59-64). Lutan (1988, pp.305-307) menambahkan gerak otomatis adalah capaian gerak yang di dalamnya sudah mengandung unsur kreativitas.

Terdapat kemiripan antara ciri-ciri capaian hasil pembelajaran rebab, kendang, dan gender barung hasil pengamatan kelas dengan ciri-ciri capaian gerak dalam teori (belajar) gerak. Kemiripan yang dimaksud adalah belum mampu memainkan cengkok lugu mirip dengan gerak kognitif. Gerak kognitif adalah gerak yang mengandung banyak kesalahan dan kesalahan tersebut cenderung berat tersebut sejajar dengan capaian belajar rebab, kendang, dan gender barung yang belum mampu memainkan cengkok lugu dengan ciri tabuhannya belum lancar atau sering berhenti sebelum penyajian selesai.

Capaian gerak asosiatif mirip dengan capaian belajar rebab, kendang, dan gender barung mampu memainkan cengkok lugu. Keduanya mempunyai ciri gerak yang sudah lebih baik dibandiing gerak kognitif, tetapi masih terdapat kesalahan yang cenderung ringan. Kesalahan ringan dalam capaian belajar rebab, kendang, dan gender barung misalnya rebab salah mengajak ngelik; sedangkan dalam gerak asosiatif kesalahan tersebut adalah kesalahan yang lansung bisa diperbaiki.

Capaian belajar gerak terampil mirip dengan capaian belajar rebab, kendang, dan gender barung cengkok sudah diberi wiledan. Ciri gerak terampil adalah tidak ada lagi kesalahan gerak, koordinasi antaranggota tubuh luwes, dan gerak sudah dioptimalisasikan.

Capaian gerak kreatif mirip dengan hasil pembelajaran rebab, kendang, dan gender barung dengan ciri cengkok sudah dikem-bangkan. Ciri kedua gerak tersebut adalah sudah mengembangkan pola gerak yang dasar, dalam teori gerak disebut gerak kreatif, sedangkan dalam hasil pembelajaran karawitan berupa kemampuan mengembangkan cengkok.

Teori tersebut digunakan untuk penyusunan indikator hasil pembelajaran keterampilan memainkan rebab, kendang, dan gender barung.

Prosedur Pengembangan Konstruk Instrumen Sikap

Pengembangan konstruk instrumen sikap menggunakan langkah-langkah sebagai berikut (identifikasi tujuan ukur, pembatasan kawasan ukur, dan Opersionalisais konsep Azwar, 2005, p.11). Identifikasi tujuan ukur adalah merumuskan tujuan penilaian sikap; yang dalam penilaian ini adalah menilai hasil pembelajaran sikap kognitif, sikap afektif, dan sikap psikomotorik atau menilai keterampilan memainkan rebab, kendang, dan gender barung dari perspektif pemahaman, penghayatan, dan pengamalannya.

Pembatasan kawasan ukur merupakan uraian tentang komponen atau dimensidimensi sikap dan komponen objek sikap. Komponen sikap memainkan tiga ricikan tersebut adalah sikap kognitif, sikap afektif, dan sikap pisikomotorik; sedangkan komponen objek sikapnya adalah rawit atau kemampuan menguasai dan mengembangkan cengkok gender barung dan rebab atau sekaran kendang; kemampuan menyelaraskan bunyi ricikan atau raras, kemampuan mengendalikan atau mengikuti irama dan tempo gending atau rampak, dan kemampuan menyeimbangkan bunyi ricikan yang dimainkan dengan ricikan lain dalam tabuh bersama atau rempeg.

Operasionalisasi konsep merupakan penjabaran komponen objek sikap ke dalam indikator perilaku (Azwar, 2005, pp.8\&12). Perilaku tersebut merupakan deskripsi hasil pembelajaran sikap kognitif atau pemahaman materi ajar, deksripsi hasil pembelajaran sikap afektif atau penghayatan materi ajar, dan deskripsi hasil pembelajaran sikap psikomotorik atau pengamalan materi ajar (Sudijono, 2011, pp.50-59). 
Menurut Borich dan Kubiszyn (2010, pp. 120-121) tingkat pemhaman seseorang tersebut melalui tahapan sebagai berikut (a) knowledge, (b) comprehension, (c) application, (d) analysis, (e) synthesis, dan (f) evaluation. Tahapan capaian hasil belajar sikap kognitif tersebut, apabila diaplikasikan dalam tahapan capaian hasil pembelajaran rebab, kendang, dan gender barung adalah sebagai berikut (a) mengetahui jenis cengkok, irama/tempo, keselarasan bunyi, dan keseimbangan bunyi yang digunakan (b) mengetahui cara mengaplikasikan cengkok, irama/tempo, keselarasan bunyi, kesimbangan bunyi yang digunakan (c) mengetahui cara mengembangkan cengkok, irama/tempo, keselarasan bunyi, kesimbangan bunyi yang digunakan, dan (d) memilih cengkok, irama/tempo, keselarasan bunyi, dan kesimbangan bunyi secara tepat.

Indikator hasil pembelajaran sikap afektif merupakan serangkaian proses menerima pengaruh orang lain hingga mempengaruhi perilaku seseorang. Menurut Borich dan Kubiszyn (2010, pp.120-121) capaian penghayatan tersebut dimulai dari penerimaan secara terbatas atau parsial atau penerimaan tidak lengkap sebagai alternatif pandangan; kemudian ditingkatkan dan diintegrasikan ke dalam sistem kepercayaan individu. Adapun penjenjangan proses penghayatan tersebut adalah sebagai berikut: (a) recieving; (b) responding; (c) valuing; (d) organizing; dan (e) characterized by a value or value complex.

Adapun aplikasinya dalam indikator hasil pembelajaran praktik karawitan Jawa adalah (a) merasakan tabuhan sendiri; (b) merasakan tabuhan ricikan lain; (c) merespons tabuhan ricikan lain; dan (d) saling memberi dan menerima respons. Tahap merasakan tabuhan sendiri adalah capaian hasil pembelajaran ketika peserta didik belum mampu memperhatikan tabuhan ricikan lain sehingga belum dapat merasakan cengkok ricikan lain; tahap berikutnya adalah capaian hasil pembelajaran ketika peserta didik sudah dapat memperhatikan/merasakan tabuhan ricikan lain sambil memainkan ricikan; capaian hasil belajar merespons adalah kemampuan peserta didik ketika sudah mam- pu memberi tanggapan tabuhan ricikan lain; sedangkan capaian hasil pembelajaran saling menerima dan memberi respons merupakan capaian hasil pembelajaran ketika peserta sudah dapat menerima dan memberi respons musikal.

Hasil perancangan tersebut diujicobakan dalam uji koseptual dan uji lapangan. Uji coba konseptual dilaksankan dalam Focus Group Discussion (FGD) 1 dan FGD 2, Seminar Instrumen, dan Uji ahli; sedangkan Uji Lapangan meliputi Uji Coba Skala Kecil, Uji Coba Skala Besar, dan Uji Coba Utama.

\section{Data, Intrumen, dan Teknik Pengumpulan Data}

Jenis data yang dikumpulkan dalam penelitian ini adalah data kualitatif dan data kuantitatif. Data kualitatif berupa keterangan, pendapat dari subjek penelitian; sedangkan data kuantitatif berupa data hasil pembelajaran praktik karawitan yang terdiri atas data memainkan rebab, kendang, dan gender barung dalam menggarap gending dan data sikap memainkan rebab, kendang, dan gender barung (data sikap kognitif, sikap afektif, dan data sikap psikomtorik).

Instrumen yang digunakan dalam penelitian ini instrumen keterampilan dan instrumen sikap. Instrumen keterampilan adalah instrumen yang digunakan untuk mengukur kemampuan bekerja sama memainkan rebab, kendang, dan gender barung. Instrumen tersebut berupa rubrik atau pedoman pengamatan keterampilan memainkan ketiga ricikan tersebut.

Instrumen sikap yang digunakan dalam penelitian berbentuk angket. Angket merupakan cara pengumpulan data yang menggunakan sejumlah pertanyaan kepada responden yang bersedia memberikan respons sesuai permintaan peneliti (Ridwan, 2005, p.26). Tujuannya adalah mencari informasi lengkap mengenai suatu masalah dari responden mengenai sikap yang dalam penelitian ini adalah sikap peserta didik terhadap permainan gamelan Jawa, khususnya dalam menglolah melodi, keselarasan bunyi ricikan, mengendalikan atau meng-

Pengembangan Konstruk. Instrumen Hasil Belajar - 175 Budi Raharja, Suminto A. Sayuti 
ikuti irama dan tempo gending, dan keseimbangan bunyi ricikan.

Teknik pengambilan data penelitian yang digunakan pada saat ini adalah teknik observasi. Teknik observasi dalam penelitian ini digunakan untuk mengumpulkan data hasil pembelajaran praktik karawitan Jawa, khusus hasil pembelajaran rebab, kendang, dan gender barung. Observasi digunakan pada tes hasil belajar, yaitu tes yang mengukur kinerja peserta didik dalam bermain gamelan secara bersama-sama. Dalam tes tersebut sekelompok mahasiswa memainkan gending Ketawang Subakastawa Laras Slendro Patet Sanga dan Ladrang Wilujeng Laras Slendro Pathet Manyura dan sejumlah penguji mengamatinya untuk menentukan capaian belajarnya.

\section{Teknik Analisis Data}

Teknik analisis data yang digunakan dalam penelitian ini adalah teknik anlaisis data kualitatif dan teknik analisis data kuantitatif. Analisis data kualitatif tersebut merupakan analisis data yang diperoleh dari ahli (expert judgement) dan praktisi maupun subjek penelitian lain yang memberi masukan. Analisis tersebut menggunakan teknik analisis triangulasi, yaitu penggabungan berbagai metode dalam suatu kajian tentang suatu gejala tertentu yang kehandalan dan kesahihan data dijamin. Adapun caranya adalah membandingkan data yang diperoleh dari satu sumber atau metode tertentu dengan data yang didapat dari sumber atau metode lain. Terdapat empat jenis teknik analisis triangulasi, yaitu triangulasi data dari berbagai macam sumber, kedua triangulasi peneliti, ketiga triangulasi teori atau penggunaan berbagai perspektif dalam mengartikan data, dan triangulasi metode atau penggunaan beberapa metode untuk mengkaji persoalan (Denzin, 1978, pp.294-305).

Taknik analisis data kuantitatif yang digunakan dalam penelitian ini meliputi teknik analisis validitas dan reliabilitas serta teknik uji kecocokan model. Teknik analisis reliabilitas menguji konsistensi data hasil pengukuran yang dihasilkan oleh instrumen; tinggi rendahnya koefisien reliabilitas me- nunjukkan tingkat konsistensi suatu instrumen, semakin tinggi tingkat reliabilitasnya kemungkinan kesalahan pengukurannya semakin kecil. Estimasi reliabilitas dilakukan dengan mengukur korelasi antara skor aitem dengan skor total (Ghozali, 2005a, p.42). Tingkat atau derajat reliabilitas adalah koefisien antara 0,50-0,70 adalah cukup, koefisien 0,70 atau lebih dapat diterima (Litwin, 1995, p.31 dan Nunnally, 1970, p.129), koefisien antara $0,70-0,90$ adalah tinggi, sedangkan koefisien $>0,90$ adalah sempurna. Kriteria reliabilitas yang digunakan dalam penelitian ini adalah 0,70 .

Validitas menunjukkan sejauh mana hasil pengukuran yang diperoleh benarbenar mengukur objek pengukuran yang diukur. Untuk membuktikan validitas isi dilakukan melalui pernyataan ahli (Mardapi, 2008, p.18) yang dalam penelitian dilaksanakan pada Diskusi Kelompok Terfokus atau Focus Group Discussion dan Expert Judgment.

Validitas konstruk adalah validitas yang berkaitan dengan kesanggupan suatu alat ukur mengukur konsep yang diukurnya. Menurut Brown (1985, p.31) validitas berhubungan dengan tingkat kecocokan alat ukur dengan apa yang diukur. Instrumen yang mempunyai validitas konstrak berarti semua butir yang ada di dalamnya mengukur konsep yang diukur (Ancok, 2002, p.21).

Validitas konstruk dibuktikan menggunakan data muatan faktor atau loading factor yang didapat dari teknik analisis faktor. Pembuktian validitas tersebut dilakukan dengan cara mengukur nilai Kaiser Meyer Olkin mengenai Measure of Sampling Adequacy (KMO MSA) atau melihat kecukupan data untuk difaktorkan, sedangkan uji Bartlett yang bertujuan untuk mengetahui apakah terdapat hubungan antarvariabel dalam kasus multivariat, uji Rotation untuk mengetahui muatan faktor (Ghozali, 2005b, pp.4751).

Analisis faktor digunakan untuk menguji hipotesis-hipotesis mengenai eksistensi konstruk-konstruk atau untuk mencari konstruk-konstruk dalam variabel-variabel. Menurut Suyanto (1988, p.234) analisis faktor 
adalah kajian tentang kesalingtergantungan antara variabel untuk menemukan himpunan variabel baru yang jumlahnya lebih sedikit dibanding variabel semula dan menunjukkan variabel yang mana diantara variabelvariabel semula merupakan faktor-faktor persekutuan (Gorsuch, 1983, p.2).

Penggunaan metode dengan bantuan komputer untuk menilai apakah butir-butir yang beragam dalam suatu survei memiliki kebersamaan dalam suatu faktor. Melalui analisis faktor dapat dilihat apakah spesifikasi konstruk yang dikembangkan secara teoretik telah sesuai dengan konsep konstruk yang mendasarinya. Jadi secara esensial, analisis faktor adalah suatu teknik analisa penyaring untuk menganalisis saling hubungan di antara butir-butir instrumen. Dalam mengembangkan suatu tes psikologis, analisis faktor sangat relevan untuk menguji kesahihan konstruk (Litwin, p.1995).

Suatu variabel observable dinyatakan valid mengukur variabel laten apabila besarnya muatan faktor lebih besar dari ( $\lambda$ ) 0,3 (Solimun, 2002, p.81 dan Fernandes, 1984, p.28), Wijanto (2008, p.175) rentang koefisien tersebut antara $\geq 0,50$ hingga $\geq 0,70$; sedangkan menurut Azwar (2004, p.158) koefisien 0,50 bisa diterima dan koefisien kurang dari 0,30 dianggap tidak memuaskan. Kriteria yang digunakan untuk menentukan validitas dalam penelitian ini adalah 0,50 .

Uji model dilakukan dengan teknik analisis Structural Equation Model atau SEM. SEM adalah teknik analisis variabel laten, variabel indikator, dan kesalahan pengukuran secara langsung untuk mengetahui hubungan antara variabel laten satu dengan variabel lain, serta kesalahan pengukurannya. SEM merupakan analisis konfirmatori variabel-variabelnya (Sitinjak dan Sugiarto, 2006, pp.2-3). Fokus analisis pada bagian ini adalah menguji model hubungan konstruk dependen dan konstruk independen (Ghozali dan Fuad, 2005, p.3).

Uji kecocokan model yang digunakan dalam penelitian ini adalah uji kecocokan model keseluruhan. Menurut Ghozali dan Fuad (2005, pp.313-316) indikator-indikator yang digunakan dalam uji kecocokan model keseluruhan tersebut adalah (a) Chi-square; (b) perbandingan antara Chi-square dengan derajat kebebasan atau degree of freedom; (c) NCP atau Non-Centrality Parameter; (d) Root Mean Square Error of Approximation (RMSEA); (e) Expected Cross Validation Index (ECVI); (f) AIC dan CAIC; (g) NFI atau Normed Fit Index; (h) NNFI atau NonNormed Fit Index; (i) Comparative Fit Index atau CFI; (j) IFI atau Incremental Fit Index, dan $(\mathrm{k})$ Relative Fit Index atau RFI.

Chi-square menguji hubungan atau pengaruh dua buah variabel nominal dan mengukur kuatnya hubungan antara variabel yang satu dengan variabel nominal lainnya. Indikator kedua adalah $p$-value, yaitu menunjukkan perbedaan nilai antara matrik input dengan hasil estimasi atau korelasi. Pvalue tidak sama dengan nol atau lebih besar dari 0,05 atau 0,1 mengindikasikan hasil uji tidak signifikan. Indikator ketiga adalah Noncentrality Parameter (NCP), yaitu statistik yang dibuat untuk menambal kelemahan dari statistik chi square. Tidak ada acuan yang pasti mengenai nilai NCP untuk mengatakan bahwa model yang diujikan cocok; hanya saja semakin kecil nilainya semakin baik.

Indikator keempat adalah The Root Mean Square Error of Approximation atau RMSEA. RMSEA berfungsi sebagai kriteria pemodelan struktur kovarian dengan mempertimbangkan kesalahan yang mendekati populasi. RMSEA menunjukkan kecocokan model atau fit apabila nilainya lebih kecil dari 0,05 , reasonable jika lebih kecil dari 0,08, cukup jika kurang dari 0,1 ; sedangkan dikatakan buruk apbila lebih dari 0,1. Indikator selanjutnya adalah NFI dan NNFI. NFI mirip dengan NNFI, hanya saja NFI memiliki rentang nilai dari 0 hingga 1 , sedangkan nilai NFI yang mendekati 0,90 mengindikasikan model yang baik. Selanjutnya adalah indikator Adjusted Goodness of Fit Index atau AGFI, NNFI, NFI, Relative Fit Index (RFI), Incremental Fit Index (IFI), dan Comparative Fit Index (CFI) yang pengujiannya menggunakan kriteria yang tertera dalam output uji kecocokan model tersebut. 
Pemaknaan data berdasarkan analisis tersebut adalah sebagai berikut. Pertama membuktikan validitas dan estimasi reliabilitas; data yang dinyatakan valid dan reliabel berarti instrumen yang digunakan untuk mengambil data tersebut mempunyai keajegan data meskipun dilakukan dalam waktu yang berbeda, sedangkan dinyatakan valid berarti instrumen yang digunakan tersebut menghasilkan seseuai dengan data yang diukur atau diharapkan. Analisis kecocokan model bermakna bahwa seluruh data dinyatakan fit atau cocok, konstruk instrumen yang dirancang sudah sesuai atau cocok dengan data lapangan atau diterima.

\section{Hasil Pengembangan dan Pembahasan}

Hasil Pengembangan Konstruk Instrumen

Hasil pengembangan konstruk instrumen hasil pembelajaran praktik karawitan ini adalah konstruk instrumen hasil pembelajaran rebab, kendang, dan gender barung. Konstruk-konstruk tersebut terdiri atas variabel laten dependen keterampilan dengan indikator rawit, laras, rampak, rempeg dan variabel independen sikap dengan indikator sikap kognitif, sikap afektif, dan sikap psikomotor.

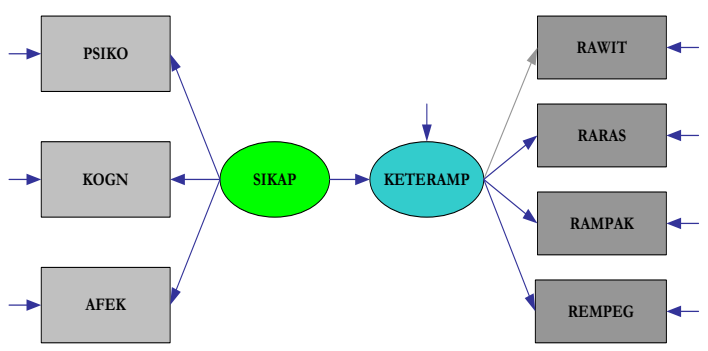

Gambar 1. Konstruk Hipotetis Penilaian Hasil Pembelajaran Rebab, Kendang, dan Gender Barung

Hasil Pengembangan Instrumen

\section{Hasil Pengembangan Instrumen Keterampilan.}

Hasil pengembangan instrumen keterampilan adalah instrumen berbentuk rubrik dengan format penulisan empat kolom (kolom aspek, kolom bobot, kolom skor, dan kolom indikator). Kolom aspek terdiri atas empat baris yang berisi aspek-aspek ke- terampilan memainkan rebab, kendang, dan gender barung (rawit, raras, rampak, dan rempeg); kolom bobot terdiri atas empat baris yang berisi bobot masing-msing aspek keterampilan $(4,3,3,2)$; kolom skor terdiri atas enam belas baris yang terbagi dalam empat kelompok (masing-masing kelompok baris berisi angka/skor 1, 2, 3, 4); dan kolom indikator terdiri atas enam belas baris yang terbagi dalam empat kelompok (masingmasing kelompok berisi empat indikator capaian aspek keterampilan tingkat tertinggi hingga terendah).

Indikator instrumen keterampilan terdiri atas indikator rawit, raras, rampak, dan indikator rempeg. Indikator rawit rebab dan gender barung adalah indikator capaian hasil pembelajaran pengolahan cengkok rebab dan gender barung dari capaian belum mampu memainkan cengkok lugu, kemudian mampu memainkan cengkok lugu, mampu memainkan cengkok yang diberi wiledan, dan mampu memainkan cengkok yang diberi wiledan dan bervariasi. Kemampuan memainkan cengkok lugu diukur dari kesesuaian cengkok yang dimainkan dengan cengkok yang diberikan dalam pembelajaran, kemampuan memberi wiledan mengidentifikasi ada tidaknya ornamen cengkok pada cengkok yang dimainkan, sedangkan kemampuan mengembangkan cengkok mengidentifikasi ada tidaknya variasi cengkok yang dimainkan peserta didik.

Indikator-indikator tersebut, apabila dikaitkan dengan pemberian skor, adalah sebagai berikut. Belum mampu memainkan cengkok lugu diberi skor 1, mampu memainkan cengkok lugu mendapat skor 2, mampu memainkan cengkok yang diberi wiledan atau ornamen diberi skor 3, dan mampu memainkan cengkok yang diberi wiledan dan bervariasi mendapat skor 4 .

Indikator rawit kendang adalah indikator hasil pembelajaran menguasai dan mengembangkan sekaran kendang. Adapun indikator selengkapnya adalah belum mampu memainkan cengkok lugu mendapat skor 1, mampu memainkan cegkok lugu diberi skor 2, mampu memainkan cengkok lugu yang diberi isen-isen mendapat skor 3, sedangkan 
capaian tertinggi adalah mampu memainkan cengkok dan isen-isen yang diberi ornamen atau wiledan diberi skor 4 .

Indikator laras ricikan rebab mengidentifikasi kenyaringan, keselarasan, dan proporsionalitas bunyi rebab. Indikator laras rebab tersebut adalah sebagai berikut (a) suara belum nyaring, (b) suara nyaring, (c) suara nyaring dan proporsional, dan (d) suara nyaring dan proporsional serta nada sesuai nada gamelan. Apabila dikaitkan dengan perolehan skor masing-masing indikator, indikator (a) mendapat skor 1, indikator (b) mendapat skor 2, indikator (c) mendapat skor 3, dan indikator (d) mendapat skor 4.

Indikator laras kendang adalah sebagai berikut (a) bunyi belum nyaring, (b) bunyi nyaring, (c) bunyi nyaring dan sesuai bunyi gamelan, dan (d) bunyi nyaring dan proporsional serta bunyi sesuai laras gamelan. Apabila dikaitkan dengan perolehan skor, indikator (a) mendapat skor 1, indikator (b) mendapat skor 2, indikator (c) mendapat skor 3, dan indikator (d) mendapat skor 4.

Indikator laras gender barung adalah sebagai berikut (a) suara belum nyaring, (b) suara nyaring, (c) suara nyaring dan proporsional, dan (d) suara nyaring dan proporsional serta jelas. Apabila dikaitkan dengan perolehan skor, indikator (a) mendapat skor 1, indikator (b) mendapat skor 2, indikator (c) mendapat skor 3, dan indikator (d) mendapat sekor 4 .

Indikator rampak rebab dan gender barung mengidentifikasi ketepatan irama/ tempo, variasi ritme, dan kualitas irama/ tempo. Indikator rampak rebab dan gender barung tersebut adalah sebagai berikut. (a) ritme belum benar, (b) ritme benar, (c) ritme benar dan bervariasi, dan (d) ritme benar, bervariasi, dan semeleh. Indikatorindikator tesebut, apabila dikaitkan dengan perolehan skor adalah sebagai berikut indikator (a) memperoleh skor 1, indikator (b) mendapat skor 2, indikator (c) diberi skor 3, dan indikator (d) diberi skor 4.

Indikator rampak untuk kendang adalah sebagai berikut. (a) irama/tempo belum tepat, (b) irama/tempo tepat, (c) irama/ tempo tepat dan menggunakan ater-ater, dan (d) irama/tempo tepat, menggunakan aterater, dan semeleh. Indikator-indikator tesebut, apabila dikaitkan dengan penskoran adalah indikator (a) memperoleh skor 1, indikator (b) mendapat skor 2, indikator (c) diberi skor 3, dan indikator (d) diberi skor 4.

Indikator rempeg mendeskripsikan kualitas keseimbangan bunyi yang dinyatakan dalam frekuensi keseimbangan bunyi. Adapun indikator-indikator tersebut adalah sebagai berikut (a) tidak pernah seimbang, (b) jarang seimbang, (c) sering seimbang, dan (d) selalu seimbang. Indikator-indikator tersebut, apabila dikaitkan dengan perolehan skor adalah sebagai berikut indikator (a) memperoleh skor 1, indikator (b) mendapat skor 2, indikator (c) diberi skor 3, dan indikator (d) diberi skor 4.

Hasil pengembangan pembobotan penilaian hasil pembelajaran praktik karawitan Jawa adalah sebagai berikut. Berdasarkan tingkat kesulitan memproduksi bunyi dihasilkan empat kelompok pembobotan penilaian. Keempat kelompok tersebut adalah (1) kelompok pembobotan rebab, kendang, dan gender barung; (2) kelompok pembobotan bonang barung, bonang penerus, (3) kelompok pembobotan balungan dan saron penerus, serta (4) kelompok pembobotan ketuk-kempyang, kenong, kempul, dan gong; sedangkan berdasarkan aspeknya, aspek rawit diberi bobot empat, aspek raras mendapat bobot tiga, sedangkan aspek rampak dan rempeg diberi bobot dua.

Hasil pengembangan kriteria ketuntasan adalah "peserta didik dapat memainkan cengkok dasar dengan lancar dengan toleransi kesalahan ringan”. Kesalahan ringan yang dimkasud adalah kesalahan yang diakibatkan lupa urutan penyajiannya, misalnya pengrebab lupa mengajak pemain lain memainkan cengkok ngelik. Indikator tersebut, apabila ditempatkan dalam rangkaian capaian belajar memainkan gamelan, sejajar dengan kemampuan memainkan cengkok dasar.

\section{Hasil Pengembangan Instrumen Sikap}

Hasil pengembangan instrumen sikap tersebut adalah alat ukur sikap peserta didik 
memainkan rebab, kendang, dan gender barung dari perspektif ranah kognitif, ranah afektif, dan ranah psikomotorik. Instrumen terdiri atas 36 (tiga puluh enam) pernyataan hasil pembelajaran; dua belas pernyataan hasil pembelajaran ranah kognitif, dua belas pernyataan hasil pembelajaran ranah afektif, dan dua belas pernyataan hasil pembelajaran ranah psikomotorik.

Instrumen tersebut berbentuk kuesioner tertutup, yaitu alat pengumpulan data berbentuk pertanyaan atau pernyataan mengenai suatu objek penelitian. Pernyataan berupa pernyataan kemampuan memainkan ricikan rebab, kendang, dan gender barung. Pernyataan tersebut untuk mengungkap pengamalan melodi, irama/tempo, keselarasan bunyi, dan keseimbangan bunyi; pemahaman melodi, irama/tempo, keselarasan bunyi, dan keseimbangan bunyi; dan penghayatan melodi, irama/tempo, keselarasan bunyi, dan keseim-bangan bunyi.

Adapun contoh dari masing-masing pernyataan tersebut adalah sebagai berikut. Pernyataan aspek rawit ranah psikomotorik adalah "Pengrebab harus dapat memainkan cengkok yang diberi wiledan dan bervariasi", pernyataan ranah kognitif "Pengrebab harus menguasai teknik produksi cengkok/lagu rebab dengan baik", pernyataan ranah afektif "Pengrebab harus dapat membedakan cengkok rebaban yang menggunakan wiledan dengan cengkok dasar".

Skor yang digunakan dalam pengembangan instrumen adalah skor satu sampai dengan empat. Skor-skor tersebut digunakan untuk memberi derajat pilihan jawaban Sangat Setuju (SS), Setuju (S), Tidak Setuju (TS), dan Sangat Tidak Setuju (STS). Pilihan jawaban sangat tidak setuju dipilih ketika responden yakin sekali bahwa pernyataan tersebut tidak sesuai dengan keadaan sesungguhnya atau dirasakan responden, sedangkan pilihan sangat setuju dipilih ketika responden yakin bahwa pernyataan tersebut sesuai dengan kenyataan atau yang dirasakan responden. Dua pernyataan lainnya, TS (tidak setuju) dan S (setuju), dipilih apabila keyakinan responden atas pernyataan tersebut tidak yakin sepenuhnya atau berada di antara dua pernyataan Sangat Setuju dan Tidak Setuju.

Bentuk pernyataan kesetujuan atau bentuk pernyataan positif digunakan dalam instrumen hasil pengembangan tersebut. Pemberian skor pernyataan tersebut berbanding lurus dengan pernyataan, maksudnya pilihan jawaban dengan tingkat kesetujuan tinggi mendapat skor tinggi dan sebaliknya pilihan jawab dengan tingkat kesetujuan rendah mendapat skor rendah. Pilihan jawaban yang dimaksud adalah pilihan jawaban sangat setuju merupakan tingkat kesetujuan tertinggi (mendapat skor 4) sedangkan pilihan jawaban sangat tidak setuju merupakan pilihan jawaban dengan tingkat kesetujuan terendah (skor 1). Skor dua pilihan jawaban lainnya, setuju mendapat skor 3 dan tidak setuju mendapat skor 2 .

\section{Hasil Uji Coba Konseptual}

Uji coba konseptual merupakan penilaian atas hasil rancangan berdasarkan konsep-konsep yang mendasarinya. Berdasarkan uji coba tersebut, ditemukan penggunaan istilah yang kurang tepat pada indikator instrumen keterampilan. Istilah-istilah yang dimaksud adalah cengkok lugu diganti dengan cengkok dasar; bunyi nyaring dan proporsional serta bunyi sesuai laras gamelan (indikator rebab) diganti dengan embat alam; istilah laras dinganti dengan raras, cengkok kendang diganti dengan sekaran kendang. Revisi pertama cengkok lugu diganti dengan cengkok dasar karena istilah lugu lebih tepat digunakan untuk menyebut cengkok yang tidak diberi wiledan; cengkok yang digunakan untuk menggarap gending berwatak tenang. Kedua penggunaan embat alam untuk mengganti indikator suara nyaring dan proporsional serta nada sesuai nada gamelan karena indikator ebat alam lebih mudah dipahami dan semakin memperjelas gradasi; sedangkan sekaran menggantikan cengkok kendang karena sekaran lebih tepat digunakan untuk menyebut pola ritme kendang, sedangkan cengkok untuk menyebut pola melodi.

Penggantian istilah akibat kesalahan konsep terjadi pada indikator rempeg. Indikator yang semula selalu seimbang, sering 
seimbang, jarang seimbang, tidak pernah seimbang kurang sesuai dengan konsep rempeg karawitan Jawa. Konsep rempeg dalam karawitan Jawa bukan dalam pengertian volume tabuhan yang sama rata, tetapi tabuhan yang keras-lirihnya sesuai porsi masing-masing; ada tabuhan yang lirih dan merata (rebab, kendang, gender barung, dan sejenis-nya), ada tabuhan yang lebih keras (kenong, kempul), dan ada tabuhan yang sangat keras (gong). Indikator tersebut kemudian diganti dengan "belum mampu menyeimbangan bunyi" "mampu menyelaraskan berdasarkan tempo gending", "mampu penyelaraskan bunyi dengan bunyi ricikan lain", dan "mampu mengelola bunyi untuk membentuk dinamika cengkok/mengendalikan tempo gending".

Hasil koreksi selanjutnya adalah penggunaan indikator ganda atau lebih dari satu membingungkan responden karena banyak indikator yang diamati diperkirakan mempengaruhi hasil pengumpulan data. Indkator yang dimaksud misalnya "ritme benar, bervariasi, dan semeleh" yang digunakan pada indikator irama/ritme. Indikator tersebut pada dasarnya merupakan serangkaian capaian hasil pembelajaran; oleh karena itu revisi atas indikator tersebut dapat dilakukan dengan cara menggunakan indikator teratas (semeleh) dengan asumsi ketika seorang pemain telah mencapai tahapan tersebut mereka sudah mencapai tahapan sebelumnya.

Revisi redaksional merupakan koreksi selanjutnya. Revisi tersebut meliputi penggunaan istilah, misalnya "memainkan cengkok bervariasi" diganti "memainkan cengkok secara bervariasi"; dan "memainkan cengkok rebaban gending Subakastawa yang bervariasi" dirubah menjadi "memainkan cengkok rebaban secara bervariasi".

Hasil perancangan pembobotan telah terjadi ketidakadilan pada pembobotan aspek rampak untuk rebab, kendang, dan gender barung yang disamakan dengan pembobotan bonang barung, bonang penerus, saron barung, dan saron penerus. Perbaikan atas pembobotan tersebut dilakukan dengan menaikkan pembobotan tiga ricikan tersebut dari bobot 2 menjadi 3 .

Revisi isntrumen sikap meliputi revisi pernyataan sikap yang semula mirip dibuat bervariasi, penggunaan indikator ganda diganti indikator tunggal, dan pilihan jawaban skala sikap diganti dengan pilihan ganda uraian singkat.

Setelah diadakan uji konseptual produk, terjadi perubahan konstruk hipotetik penilaian hasil pembelajaran kendang. Perubahan terjadi karena dalam hasil pembelajaran kendang tidak ditemukan indikator sikap rawit ranah psikomotorik sehingga variabel hasil pembelajaran kendang yang semula tiga (psikomotorik, afektik, kognitif) menjadi dua indikator, tanpa sikap afektif.

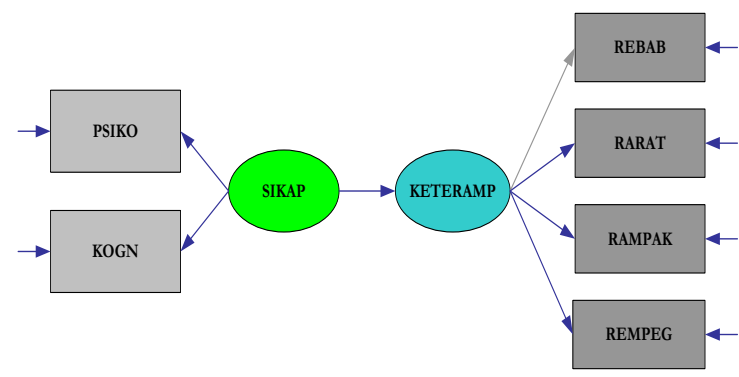

Gambar 2. Revisi Konstruk Penilaian Hasil Pembelajaran Kendang

\section{Hasil Uji Coba Lapangan}

Hasil uji coba lapangan merupakan laporan hasil analisis data hasil pembelajaran yang didapat dari penggunaan instrumen hasil rancangan. Laporan tersebut terbagi dalam tiga, yaitu uji coba skala kecil, skala besar, dan uji coba utama. Hasil uji coba skala kecil berupa laporan tingkat validitas dan reliabilitas dengan responden dosen dan responden ma-hasiswa; hasil uji coba skala besar melaporkan validitas dan relibailitas serta uji kecocokan model dengan responden dosen; hasil uji coba utama melaporkan hasil analisis uji kecocokan model dengan responden dosen.

Analisis tersebut menguji data hasil pembelajaran keterampilan yang terdiri atas aspek rawit, raras, rampak, rempeg dan hasil pembelajaran sikap yang terdiri atas aspek rawit ranah kognitif, afektif, psikomotorik; aspek raras ranah kognitif, afektif, psikomo- 
torik; aspek rawit ranah afektif untuk ricikan rebab dan gender barung; sedangkan untuk hasil pembelajaran kendang tanpa aspek rawit ranah afektif.

\section{Hasil Uji Coba Lapangan Skala Kecil}

Hasil analisis data uji coba skala kecil ini menguji 30 data hasil pembelajaran dengan responden dosen (data keterampilan dan sikap) dan responden mahasiswa (data hasil pembelajaran sikap).

Hasil analisis data hasil belajar rebab dengan responden dosen untuk data hasil belajar keterampilan semuanya valid dan reliabel; sedangkan untuk data hasil pembelajaran sikap terdapat dua aspek belum reliabel, yaitu aspek rawit ranah psikomotorik $(0,687)$ dan aspek rempeg ranah kognitif $(0,697)$ belum kriteria reliabilitas sebesar 0,70 . Setelah diadakan perbaikan dan dianalisis hasil semua reliabel dan valid.

Hasil analisis data hasil belajar kendang dengan responden dosen untuk data hasil pembelajaran keterampilan semuanya valid dan reliabel, sedangkan data pembelajaran sikap terdapat satu aspek yang belum reliabel (aspek raras ranah kognitif sebesar $0,697)$. Data yang belum reliabel diperbaiki dengan cara mengambil data ulang dan menjadi valid dan reliabel semuanya.

Hasil analisis data hasil belajar gender barung dengan responden dosen untuk data hasil pembelajaran keterampilan semuanya valid dan reliabel, sedangkan hasil belajar sikap terdapat dua aspek yang belum reliabel; aspek rawit ranah psikomotorik $(0,691)$ dan rempeg ranah kognitif sebesar $(0,696)$. Hasil perbaikan data pertama masih terdapat satu indikator yang belum memenuhi kriteria reliabilitas (aspek raras ranah kognitif) dan setelah diperbaiki lagi semuanya valid dan reliabel.

Hasil analisis data hasil pembelajaran sikap dengan responden mahasiswa adalah sebagai berikut. Hasil analisis data hasil pembelajaran rebab aspek rawit ranah afektif belum reliabel dan belum valid, aspek rawit ranah afektif, aspek rampak ranah psikomotorik dan aspek rempeg ranah kognitif sudah valid tapi belum reliabel; sedangkan aspek dan ranah lainnya sudah reliabel dan valid. Data yang belum valdi dan belum reliabel tersebut diperbaiki dan hasilnya data aspek raras ranah psikomotorik dan hasil pembelajaran aspek rempeg ranah kognitif belum reliabel.

Hasil analisis tersebut data sikap memainkan kendang dengan responden mahasiswa semua valid, tetapi belum semuanya reliabel; aspek raras ranah psikomotorik $(0,696)$ dan aspek rempeg ranah kognitif $(0,606)$ belum reliabel. Data yang belum reliable diperbaiki dan hasilnya data aspek raras ranah psikomotorik $(0,676)$, aspek rempeg ranah psikomotorik $(0,684)$, dan aspek rempeg ranah kognitif $(0,612)$ belum reliabel.

Hasil analisis data gender barung responden mahasiswa terdapat data yang belum valid (aspek rawit ranah afektif 0,457 dan 0,476) dan yang belum reliabel adalah data aspek rampak ranah kognitif $(0,676)$, dan data aspek rempeg ranah kognitif $(0,631)$. Hasil pengambilan data kedua menunjukkan enam aspek valid dan reliabel sedangkan tiga lainnya valid tetapi belum reliabel; yaitu aspek rawit ranah afektif $(0,673)$; koefisien aspek raras ranah kognitif $(0,647)$; dan aspek rempeg ranah kognitif $(0,632)$.

Hasil uji coba tersebut memberi informasi bahwa data dengan responden dosen lebih valid dan reliabel; untuk itu pengambilan data selanjutnya menggunakan responden dosen.

\section{Hasil Uji Coba Lapangan Skala Besar}

Hasil analisis data uji coba skala besar ini menguji 60 data hasil pembelajaran rebab, kendang, dan gender barung. Hasil analisis hasil pembelajaran rebab semuanya valid dan reliabel, tapi belum fit. Indikasinya adalah nilai RMSEA 0,094 belum sesuai dengan kriteria $\leq 0,080$. Indikator tersebut menginformasikan bahwa dalam data tersebut masih terdapat data yang belum fit.

Pelacakan atas data belum fit dilakukan dengan cara mengidentifikasi kelompok data yang menguatkan atau kelompok data yang melemahkan kecocokan model. Caranya setiap kelompok lima data dikeluarkan dari tabel kemudian dianalisis dengan meng- 
hitung nilai P dan nilai RMSEAnya; apabila nilai indikator kecocokan model naik maka fungsi kelompok data tersebut melemahkan dan apabila nilai indikator turun maka fungsi kelompok data tersebut menguatkan.

Setelah dilakukan analisis ditemukan data 35 hingga 40 belum fit. Lima data tersebut diperbaiki dan setelah itu disatukan kembali dengan lain dan dianalisis hasilnya fit. Adapun hasil analisis tersebut disajikan pada Tabel 1.

Tabel 1. Data Hasil Analisis Kecocokan Model Ricikan Rebab (Data 60)

\begin{tabular}{llll}
\hline No Indikator & Hasil & Kriteria & Ket. \\
\hline 1. P value & 0,41011 & $\geq 0,05$ & Fit \\
2. Chi-square & 13,50 & $\neq 0$ & Fit \\
3. Chi-square/df & 1,038462 & $<5$ atau $<2$ & Fit \\
4. NCP & 0,50 & $(0,0 ; 13.55)$ & Fit \\
5. RMSEA & 0,025 & $\leq 0,08$ & Fit \\
6. ECVI & 0,74 & $(0,73 ; 0,96)$ & Fit \\
7. AIC & 43,50 & $<56.00$ & Fit \\
8. CAIC & 89,91 & $<142,64$ & Fit \\
9. NFI & 0,96 & $>0,9$ & Fit \\
10. NNFI & 0,99 & $>0,95$ & Fit \\
11. CFI & 0,99 & $(1: 0,9)$ & Fit \\
12. IFI & 1,00 & $>0,9$ & Fit \\
13. RFI & 0,94 & $(0: 1)$ & Fit \\
\hline
\end{tabular}

Hasil analisis hasil pembelajaran kendang semuanya valid dan reliabel, tapi belum fit. Terdapat 5 indikator yang belum fit; nilai $P=0,004$ belum sesuai kriteria $\geq 0,050$; nilai RMSEA sebesar 0,178 yang belum sesuai kriteria $\leq 0,080$; nilai ECVI sebesar 0,83 yang belum sesuai dengan kriteria $(0,095: 0,27)$; nilai AIC sebesar 48,90 yang belum sesuai kriteria $<42.00$; nilai NNFI sebesar 0,90 yang belum sesuai dengan kriteria $>0,95$.

Setelah dilakukan analisis, seperti cara sebelumnya, ditemukan empat data belum fit. Data tersebut diperbaiki, dan setelah itu disatukan kembali dengan lain dan dianalisis, hasilnya fit. Adapun hasil analisis tersebut disajikan pada Tabel 2.
Tabel 2. Data Hasil Analisis Kecocokan Model Ricikan Kendang (Data 60)

\begin{tabular}{llll}
\hline No Indikator & Hasil & Kriteria & Ket \\
\hline 1. P value & 0,27049 & $\geq 0,05$ & Fit \\
2. Chi-square & 9,92 & $\neq 0$ & Fit \\
3. Chi-square/df & 1,24 & $<5 /<2$ & Fit \\
4. NCP & 1,92 & $(0,00 ; 14,19)$ & Fit \\
5. RMSEA & 0,064 & $\leq 0,08$ & Fit \\
6. ECVI & 0,61 & $(0,58 ; 0,82)$ & Fit \\
7. AIC & 35,92 & $<42.00$ & Fit \\
8. CAIC & 76,15 & $<106,98$ & Fit \\
9. NFI & 0,97 & $>0,9$ & Fit \\
10. NNFI & 0,99 & $>0,95$ & Fit \\
11. CFI & 0,99 & $(1: 0,9)$ & Fit \\
12. IFI & 0,99 & $>0,9$ & Fit \\
13. RFI & 0,94 & $(0: 1)$ & Fit \\
\hline
\end{tabular}

Hasil analisis hasil pembelajaran gender barung semuanya valid dan reliabel, tapi belum fit. Indikatornya nilai $\mathrm{P}$ sebesar 0,35184 belum memenuhi kriteria $\geq 0,050$ dan nilai RMSEA sebesar 0,123 belum memenuhi kriteria $\leq 0,080$.

Setelah dianalisis, dengan cara yang sama dengan sebelumnya, ditemukan enam data $(37,43,44,45,48$, dan data nomor 52$)$ belum fit. Setelah data diperbaiki dan dianalisis hasilnya fit. Adapun data hasil analisis tersebut disajikan pada Tabel 3.

Tabel 3. Data Hasil Analisis Kecocokan Model Ricikan Gender Barung (Data 60)

\begin{tabular}{|c|c|c|c|}
\hline No Indikator & Hasil & Kriteria & Ket. \\
\hline 1. $\mathrm{P}$ value & 0,49969 & $\geq 0,05$ & Fit \\
\hline 2. Chi-square & 12,34 & $\neq 0$ & Fit \\
\hline 3. Chi-square/df & 0,949231 & $<5$ atau $<2$ & Fit \\
\hline 4. NCP & 0,00 & $(0,00 ; 11.72)$ & Fit \\
\hline 5. RMSEA & 0,000 & $\leq 0,08$ & Fit \\
\hline 6. ECVI & 0,73 & $(0,73 ; 0,93)$ & Fit \\
\hline 7. AIC & 42,34 & $<56.00$ & Fit \\
\hline 8. CAIC & 88,76 & $<142,64$ & Fit \\
\hline 9. NFI & 0,97 & $>0,9$ & Fit \\
\hline 10. NNFI & 1,00 & $>0,95$ & Fit \\
\hline 11. CFI & 1,00 & $(1: 0,9)$ & Fit \\
\hline 12. IFI & 1,00 & $>0,9$ & Fit \\
\hline 13. RFI & 0,95 & $(0: 1)$ & Fit \\
\hline
\end{tabular}




\section{Hasil Uji Kecocokan Model}

Laporan hasil uji coba kecocokan model ini merupakan hasil analisis 198 data. Hasil analisis data hasil pembelajaran rebab belum sesuai dengan model; karena nilai $\mathrm{P}$ dan nilai AIC belum memenuhi criteria (nilai P 0,01563 belum sesuai kriteria $\geq$ 0,050 dan nilai AIC 58,99 juga belum sesuai kriteria $<56,00)$.

Setelah dianalsis dengan cara yang sama dengan penelusuran data belum fit laporan uji coba skala besar ditemukan data belum fit, yaitu data nomor 11 hingga 30 . Setelah diperbaiki, disatukan kembai, dan dianalisis hasil semua data fit. Adapun hasil analisis tersebut disajikan pada Tabel 4 .

Tabel 4. Data Hasil Analisis Kecocokan Model Ricikan Rebab (Data 198)

\begin{tabular}{llll}
\hline No Indikator & Hasil & Kriteria & Ket. \\
\hline 1. P value & 0,06849 & $\geq 0,05$ & Fit \\
2. Chi-square & 12,14 & $\neq 0$ & Fit \\
3. Chi-square/df & 1,6331 & $<5$ atau $<2$ & Fit \\
4. NCP & 8,23 & $(0,00 ; 24,96)$ & Fit \\
5. RMSEA & 0,057 & $\leq 0,08$ & Fit \\
6. ECVI & 0,26 & $(0,22 ; 0,34)$ & Fit \\
7. AIC & 51,23 & $<56.00$ & Fit \\
8. CAIC & 115,55 & $<176,07$ & Fit \\
9. NFI & 0,99 & $>0,9$ & Fit \\
10. NNFI & 0,99 & $>0,95$ & Fit \\
11. CFI & 1,00 & $(1: 0,9)$ & Fit \\
12. IFI & 1,00 & $>0,9$ & Fit \\
13. RFI & 0,98 & $(0: 1)$ & Fit \\
\hline
\end{tabular}

Hasil uji kecocokan model data hasil pembelajaran kendang adalah jumlah data 198 tersebut setelah dianalisis data tersebut belum fit. Indikatornya nilai P 0,00903 belum sesuai kriteria $\geq 0,05$, nilai RMSEA 0,089 belum sesuai kriteria $\leq 0,08$ dan AIC hasil penghitungan adalah 46,37 yang belum sesuai kriteria $<42,00$.

Setelah dianalsis ditemukan data belum fit, yaitu data nomor 133 hingga 137. Setelah diperbaiki, disatukan kembali, dan dianalisis hasil semua data fit. Adapun hasil analisis tersebut disajikan pada Tabel 5 .
Tabel 5. Data Hasil Analisis Kecocokan Model Ricikan Kendang

(Data 198)

\begin{tabular}{llll}
\hline No Indikator & Hasil & Kriteria & Ket. \\
\hline 1. P value & 0,05614 & $\geq 0,05$ & Fit \\
2. Chi-square & 15,16 & $\neq 0$ & Fit \\
3. Chi-square/df & 1,895 & $<5 /<2$ & Fit \\
4. NCP & 7,16 & $(0,0 ; 22,23)$ & Fit \\
5. RMSEA & 0,067 & $\leq 0,08$ & Fit \\
6. ECVI & 0,21 & $(0,17 ; 0,22)$ & Fit \\
7. AIC & 41,16 & $<42,00$ & Fit \\
8. CAIC & 96,91 & $<132,05$ & Fit \\
9. NFI & 0,99 & $>0,9$ & Fit \\
10. NNFI & 0,99 & $>0,95$ & Fit \\
11. CFI & 0,99 & $(1: 0,9)$ & Fit \\
12. IFI & 0,99 & $>0,9$ & Fit \\
13. RFI & 0,98 & $(0: 1)$ & Fit \\
\hline
\end{tabular}

Hasil analisis data hasil pembelajaran gender barung memberikan informasi bahwa nilai $\mathrm{P} 0,0085$ belum sesuai kriteria $\geq 0,05$ dan nilai AIC adalah 58,99 yang belum sesuai kriteria $<56,00$. Hasil analisis tersebut mengindikasikan bahwa dalam data tersebut masih ada data yang belum cocok dengan model.

Setelah dianalsis ditemukan data belum fit, yaitu data nomor 2, 81-90, dan 101-110. Setelah diperbaiki, disatukan kembai, dan dianalisis hasil semua data fit. Adapun hasil analisis tersebut adalah sebagai berikut.

Tabel 6. Data Hasil Analisis Kecocokan Model Ricikan Gender Barung

(Data 198)

\begin{tabular}{lllll}
\hline No Indikator & Hasil & Kriteria & Ket. \\
\hline 1. & P value & 0,21313 & $\geq 0,05$ & Fit \\
2. & Chi-square & 16,71 & $\neq 0$ & Fit \\
3. & Chi-square $/$ df & 1,285285 & $<5$ atau $<2$ & Fit \\
4. & NCP & 3,71 & $(0,0 ; 18,42)$ & Fit \\
5. RMSEA & 0,038 & $\leq 0,08$ & Fit \\
6. ECVI & 0,24 & $(0,22 ; 0,37)$ & Fit \\
7. AIC & 46,71 & $<56.00$ & Fit \\
8. CAIC & 111,03 & $<173,09$ & Fit \\
9. NFI & 0,99 & $>0,9$ & Fit \\
10. NNFI & 1,00 & $>0,95$ & Fit \\
11. CFI & 1,00 & $(1: 0,9)$ & Fit \\
12. IFI & 1,00 & $>0,9$ & Fit \\
13. RFI & 0,99 & $(0: 1)$ & Fit \\
\hline
\end{tabular}




\section{Pembahasan}

Hasil analisis data 198 hasil pembelajaran rebab, kendang, dan gender, seluruh indikator dinyatakan fit. Hal itu mengindikasikan bahwa model yang dirancang diterima. Berdasarkan hal tersebut hasil pengembangan konstruk instrumen hasil pembelajaran tersebut dapat dijelaskan sebagai berikut.

Konstruk instrumen hasil pembelajaran rebab dan gender terdiri atas dimensi keteram-pilan dengan indikator (a) rawit, (b) raras, (c) rampak, dan (d) rempeg; dan dimensi sikap dengan indikator (1) kognitif, (2) afektif, dan (3) psikomotorik dengan pengecualian konstruk hasil pembelajaran kendang tanpa indikator ranah afektif.

Hasil pembelajaran sikap mempengaruhi hasil pembelajaran keteramipan rebab sebesar 0,92; sedangkan muatan faktor masing-masing indikatornya rawit 0,80 ; raras 0,81 ; rampak 0,75 ; rempeg sebesar 0,74 ; psikomotorik 0,77 ; kognitif 0,69 ; dan afektif 0,62 .

Hasil pembelajaran sikap kendang koefisien mempengaruhi hasil pembelajaran keterampilan memainkan kendang sebesar 0,98 ; sedangkan muatan faktor masingmasing indikatornya rawit 0,83 ; raras 0,82 ; rampak 0,82; rempek 0,81; psikomotorik 0,75 dan kognitif 0,69 .

Hasil pembelajaran sikap gender barung mempengaruhi hasil pembelajaran keterampilan memainkan gender barung sebesar 0,75 ; sedangkan muatan faktor masing-masing indi-katornya rawit 0,92 ; raras 0,89 ; rampak 0,87 ; rempeg 0,85 . Psikomotorik 0,71 ; kognitif 0,70 ; dan afektif 0,67 .

Konstruk instrumen penilaian hasil pembelajaran tersebut mengukur keterampilan memainkan gamelan Jawa dari (a) perspektif kemampuan mengembangkan melodi dan pola ritme, (b) perspektif kemampuan menyelaraskan bunyi dan tempo, serta (c) perspektif kemampuan menyeimbangkan bunyi; pemahaman melodi, pola ritme, tempo, keselarasan bunyi, dan keseimbangan bunyi, tingkat penghayatan melodi, serta tingkat pengamalan melodi, irama/tempo, keselarasan bunyi, dan keseimbangan bunyi.

Perspektif kemampuan mengembangkan melodi dan pola ritme mengukur kemampuan pemain rebab dan gender mengembangkan melodi serta pola ritme; perspektif kemampuan menyelaraskan bunyi dan tempo mengukur kemampuan peserta didik menyelaraskan bunyi dan tempo tiga ricikan tersebut; perspektif keseimbangan bunyi mengukur kemampuan peserta didik menyeimbangan tiga ricikan tersebut; perspektif pemahaman melodi, tempo, keselarasan bunyi dan keseimbangan bunyi mengukur tingkat pemahaman elemen-elemen pembelajaran praktik karawitan Jawa; sedangkan perspektif penghayatan mengukur tingkat penghayatan melodi rebab dan gender barung.

Pengembangan konstruk instrumen peni-laian hasil pengembangan praktik karawitan ini mengukur kemampuan peserta didik dari perspektif psikomotorik (keterampilan mema-inkan gamelan), perspektif kognitif (pemaham-an elemen pembelajaran), dan perspektif afektif (tingkat penghayatan elemen-elemen pembelajaran praktik karawitan Jawa).

\section{Simpulan}

Berdasarkan diskusi hasil penelitian dapat disimpulkan sebagai berikut. Penelitian "Pengembangan Konstruk Instrumen Hasil Hasil Pembelajaran Praktik Karawitka Jawa" menghasilkan konstruk instrumen hasil pembelajaran rebab, kendang, dan gender barung yang terdiri atas instrumen keterampilan dan instrumen sikap. Instrumen keterampilan mengukur kemampuan pesera didik dalam bekerja sama menggarap gending; instrumen sikap (piskomotorik) me-ngukur pemahaman melodi, irama/tempo, keselarasan bunyi, dan keseimbangan bunyi; instrumen sikap (afektif) mengukur penghayatan melodi, dan instrumen sikap (psikomotorik) mengukur pengamalan melodi, irama/tempo, keselarasan bunyi, dan keseimbangan bunyi.

Kerja sama dalam menggarap gending menilai tingkat kerumitan melodi/cengkok,

Pengembangan Konstruk Instrumen Hasil Belajar - 185 Budi Raharja, Suminto A. Sayuti 
pengendalian irama/tempo gending oleh pengendang atau penyelarasan ritme tabuhan ricikan rebab dan gender barung dengan tempo gending, kemampuan menyelaraskan nada rebab dengan nada ricikan lain oleh pengrebab atau kemampuan memproduksi bunyi kendang dan gender barung, dan kemampuan menyeimbangkan bunyi dalam tabuh bersama. Tingkat kerumitan cengkok/ sekaran menilai penguasaan dan pengembangan cengkok (rebab atau gender barung) atau sekaran (kendang); kemampuan menyelaraskan nada rebab dengan nada ricikan lain mengukur kemampuan pengrebab dalam menyamakan nada hingga menaplikasikan embat alam dalam bermain bersama, kemampuan memproduksi bunyi kendang mengukur keselarasan dan keseimbangan bunyi kendang: kemampuan bunyi gender barung mengukur kenyaringan dan keselarasan tabuhan gender barung; pengendalian tempo mengukur kesesuaian tempo dan karakter gending serta kehalusan perpindahannya; penyelarasan ritme tabuhan dengan tempo gending mengukur ketepatan dan kualitas tempo tabuhan; sedangkan menyeimbangkan bunyi dalam tabuh bersama mengukur kemampuan menyeimbangkan bunyi hingga mengolah bunyi sebagai dinamika cengkok atau untuk mengendalikan tempo gending.

Instrumen sikap kognitif mengukur pemahaman elemen-elemen pembelajaran praktik karawitan Jawa. Sikap tersebut mengukur pemahaman cengkok/sekaran, keselarasan bunyi, pengendalian/penyelarasan irama/tempo gending; merespon tabuhan ricikan lain mengukur kemapuan pemain rebab dan gender barung menanggapi tabuhan hingga kerja sama dalam menggarap cengkok, tingkat capaian belajar melodi, ira$\mathrm{ma} /$ tempo gending, keselarasan bunyi, dan keseimbangan bunyi mengukur tahapan kemampuan memproduksi komponen pembelajaran tersebut dari memproduk-sinya secara terbimbing hingga menghasilkan komponen-komponen terserbut sebagai gaya pribadi.

Instrumen sikap afektif mengukur tingkat penghayatan melodi rebab dan gender barung; sedangkan instrumen sikap psikomotorik mengukur tingkat pengamalan elemen-elemen pembelejaran praktik karawitan Jawa.

Saran

Penggunaan instrumen ini untuk karawitan gaya lain perlu hati-hati, karena uji instrumen yang dilakukan masih terbatas pada karawitan gaya Surakarta. Permasalahan yang mungkin muncul dalam penggunaan tersebut adalah indikator-indikator yang digunakan dalam instrumen ini kemungkinan tidak sesuai, oleh karena perlu peneyesuaian.

\section{Daftar Pustaka}

Ancok, Djamaludin (2002). Teknik penyusunan skala pengukur. Yogyakarta: Pusat Studi Kependudukan dan Kebijakan UGM.

Azwar, Saifuddin (2005). Penyusunan skala psikologi. Yogyakarta: Pustaka Pelajar.

Azwar, Saifuddin. (2004). Reliabilitas dan validitas. Yogyakarta: Pustaka Belajar

Borg, W R. \& Gall, M. D. (1996). Educational research, an introduction (fourth edition). New York: Longman

Borich, Gary dan Kubiszyn, Tom (2010). Educational testing \& measurement, classroom apllication and practice (nine edition). Hoboken: John Wiley \& Sons, Inc.

Brown, Frederick G. (1985). Principles of education and psychological testing. New York: Holt, Rinehart and Winston.

Denzin, Norman K. (1978). Sociology, methodology, research. New York: McGrawHill.

Djumadi. (1982). Tuntunan belajar rebab. Surakarta: Sekolah Menengah Karawitan Indonesia.

Fernandes, H.J.X. (1984). Evaluation of educational programs. Jakarta: National Educational Planning Program Evaluation and Curriculum Development.

Ghozali \& Fuad (2005). Structural equation modeling, teori, konsep, dan aplikasi dengan 
program lisrel 8.54. Semarang: Badan Penerbit Universitas Diponegoro.

Ghozali, Imam. (2005b). Aplikasi analisis multivariat dengan program spss. Semarang: Badan Penerbit Universitas Diponegoro.

Gorsuch, Richard L. (1983). Factor Analysis. Hillsdale: Lawrence Erlbaum Associates Publisher.

Johnson, David W., \& Johnson, Roger T. (2002). Meaningful assessment manageable and cooperative process. Boston: Allyn \& Bacon.

Litwin, Mark S. (1995). How to measure survey reliability and validity. London: Sage Publications.

Lutan, Rusli (1988). Belajar keterampilan motorik; pengantar teori dan metode. Jakarta: Depdikbud.

Machlis, Joseph (1955). The enjoyment of music. New York: W.W. Norton \& Company.

Magill, R. A. (1993). Motor learning, con-cept and applications, Du-buque: C. Brown Communications Inc.

Mardapi, Djemari (2004). Pengembangan sistem penilaian berbasis kompetensi dalam Rekayasa sistem penilaian dalam rangka meningkatkan kualitas pendi-dikan (71-85). Yogyakarta: Himpunan Evaluasi Pendidikan Indonesia.

Mardapi, Djemari. (2008). Teknik penyusunan instrumen tes dan nontes. Yogyakarta: Mitra Cendekia.

Martopangrawit (1975). Pengetabuan karawitan 1. Surakarta: Akademi Seni Karawitan Indonesia.

Nunnally, Jum C (1970). Introduction to psychological measurement. New York: McGraw Hill Book Company.

Popham, Jame W. (1995). Classroom assessment, what teachers need to know. Los Angeles: California University.

Prier, SJ., Karl-Edmund (1999). Sejarab musik jilid 1. Yogyakarta: Pustaka Musik Liturgi.
Ridwan (2005). Skala pengukuran variabelvariabel penelitian. Bandung: Penerbit Alfabeta.

Sayuti, Suminto A. (2004). Pendidikan seni dalam perspektif kurikulum berbasis kompetensi: beberapa catatan awal. Dalam Yayah Kusbiyah dan Atiqa Sabardila (ed). Pendidikan apresiasi seni, wacana dan praktik untuk toleransi pluralisme budaya. Surakarta: Pusat Studi dan Perubahan Sosial.

Scruton, Roger. (1999). The aesthetics of music. New York: Oxford University.

Sitinjak, T.J.R. \& Sugiarto (2006). Lisrel. Yogyakarta: Graha Ilmu.

Sodikun, Imam. (2004). Pengembangan sistem penilaian hasil belajar keterampilan gerak dalam Rekayasa sistem penilaian dalam rangka meningkatkan kualitas pendidikan (86-97). Yogyakarta: Himpunan Evaluasi Pendidikan Indonesia.

Solimun. (2002). Structural equation modeling (SEM) Lisrel dan Amos. Malang: Fakultas MIPA Universitas Brawijaya.

Sudijono, Anas (2011). Pengantar evaluasi pendidikan. Jakarta: PT Raja Garfindo Persada.

Supanggah, Rahayu (2004). Gatra: a basic concept of traditional javaneese gen-ding. Balungan, A Publication of The American Gamelan Institute, volume 9-10: 1-12.

Suyanto. (1988). Metode statistika multivariat. Jakarta: Departemen Pendidikan dan Kebudayaan.

Wijanto, Setya Hari. (2008). Structural equation modeling dengan lisrel. Yogyakarta: Graha Ilmu.

Zamroni (2004). Pengembangan sistem penilaian pendidikan menengah yang menerapkan kbk dalam kerangka otonomi daerah dalam Rekayasa sistem penilaian dalam rangka meningkatkan kualitas pendidikan (42-50). Yogyakarta: Himpunan Evaluasi Pendidikan Indonesia. 